\title{
Laboratory Studies on the Development and Life Table Parameters of Planococcus citri (Risso) (Hemiptera, Pseudococcidae) at Different Temperatures
}

\author{
M. A. El-Aw ${ }^{1}$, Kh. A. A. Draz ${ }^{1}$, H. H. Karam ${ }^{2}$, A. A. A. Khalafallah ${ }^{3}$ \\ ${ }^{1}$ Plant Protection Department, Faculty of Agriculture, Damanhour University, Egypt \\ ${ }^{2}$ Department of Applied Entomology, Faculty of Agriculture (El-Shatby), Alexandria University, \\ Egypt \\ ${ }^{3}$ Plant Protection Research Institute, Agriculture Research Center, Giza, Egypt \\ drmelaw2000@yahoo.com
}

\begin{abstract}
The development and life table parameters of Planococcus citri (Risso) were investigated at various temperatures ranging from 20 to $30^{\circ} \mathrm{C}$. The total duration of development of female mealybug was 28.2 day at $20^{\circ} \mathrm{C}, 20.8$ day at $25^{\circ} \mathrm{C}$, and 20.05 day at $30^{\circ} \mathrm{C}$. The total life cycles of $P$. citri females were $63.20,51.10$, and 41.55 days at 20,25, and $30^{\circ} \mathrm{C}$, respectively. The highest number of egg laying by female of $P$. citri was recorded at $30^{\circ} \mathrm{C}$ with an average of 340.1 eggs, while the average numbers of egg laying were 62.1 and 276.8 eggs per female at 20 , and $25^{\circ} \mathrm{C}$, respectively. The total life cycles of $P$. citri males were $43.2,30.4$, and 23.95 days at 20,25 , and $30^{\circ} \mathrm{C}$, respectively. The total number of daughters per female (Ro) obtained at $20^{\circ} \mathrm{C}$ was 62.61 compared with $136.88,380.00$ and 339.62 daughters at 25,27 and $30{ }^{\circ} \mathrm{C}$, respectively. The generation time $(G t)$ values of $P$. citri were $64.45,50,46.35$ and 44.88 day for insect reared at 20, 25, 27 and $30^{\circ} \mathrm{C}$, respectively. While intrinsic rate of natural increase $(\mathrm{rm})$ values were $0.064,0.09,0.128$ and 0.129 for insect reared at 20, 25, 27 and $30^{\circ} \mathrm{C}$, respectively. The values of total days for population to double (Dt) decreased gradually with increasing degree of temperature. These findings showed citrus mealybug performances to be highly affected by temperature.
\end{abstract}

Keywords: citrus mealy bug, Planococcus citri, development, life table parameters.

\section{INTRODUCTION}

Mealybugs had piercing-sucking mouthparts that remove plant fluids and serious infestations can lead to premature leaf drop, reduced plant vigor, and the formation of honeydew, which is an excellent growing medium for black sooty mold fungi (Serrano et al., 2001). The citrus mealy bug, Planococcus citri (Risso) (Hemiptera: Pseudococcidae) attacks many host plants including all orchard trees in Egypt (Ahmed and Abd-Rabou, 2010). The reproductive ability of its female is temperature dependent (Copeland et al., 1985). Age specific life and fertility tables have been effective tools for analyzing and realizing the impact of an external effect on the growth, survival, reproduction and intrinsic rate of increase of an insect population (Wittmeyer and Coudron, 2001). The biology of citrus mealybug has been studied on different host plants, including citrus, coffee, pumpkin, and coleus (Malleshaiah et al., 2000; Laflin and Parrella, 2004; Hogendorp et al., 2006). Life table is an important method to calculate the biological data using mathematical equations to predict the rate of population growth.

In the recent decade, the trend of increased build up of various mealybug species in crop plants and in the wild plant is observed mainly due to certain abiotic changes in climate and environment. During the last few years mealybugs, which were considered to be minor pests in many crops have acquired the status of major pests especially in cotton, vegetables and fruits (Tanwar et al., 2007).

However, the temperature-dependent responses of citrus mealybug were not studied over a wide range of constant temperatures. Thus, the main objective of this study was to determine the effect of selected different constant temperatures on the major biological parameters of the citrus mealybug, Planococcus citri such as survival, development, reproduction, and population growth and running these biological data in a computer program to estimate the life table parameters. 


\section{MATERiAls AND MethodS}

\subsection{Rearing of the Citrus Mealybug}

The stock culture of citrus mealy bug used in this study was originally collected from Alexandria Agricultural Experimental station, from infested ornamental plants. The mealybug colony was kept under laboratory coditions of $25 \pm 2^{\circ} \mathrm{C}, 60-70 \% \mathrm{RH}$ on pumpkin fruits.

\subsection{Mass Rearing}

Red potatoes (Solanum tuberosum L.) var. Kara was used as a host plant for rearing of Citrus mealybugs. The tubers were allowed to sprout and were used in rearing a colony of $P$. citri. Potatoes were soaked in a 1\% solution of bleach (Clorox; The Clorox Co., Oakland, CA; 6\% sodium hypochlorite) for $15 \mathrm{~min}$ and rinsed with water, air-dried, and placed in bags made from black cotton cloth to encourage sprouting according to Yang and Sadof (1995). Bags were kept inside dark cages at $27 \pm 2{ }^{\circ} \mathrm{C}$ and $65-75 \% \mathrm{RH}$. Every week, newly sprouted potatoes were added to the stock culture of $P$. citri to maintain the colony.

\subsection{Biology of Citrus Mealy Bug}

For studying the biology of mealybug, $P$. citri, females were confined in plastic cups $(10 \mathrm{~cm}$ high and $11 \mathrm{~cm}$ diameter) provided with kara potato. A circular hole was made in the lid of each plastic cups covered with muslin for ventilation. these cups were kept in wooden cage, $(30 \times 30 \times 30 \mathrm{~cm})$ covered with muslin except one side has a slave for examination for one generation under laboratory conditions ( $25 \pm 2 \mathrm{C}$ and RH $65-75 \%$ ).

Eggs were taken from the isolated adult females immediately after deposition and placed on potato tubers confined in plastic cups $4 \mathrm{~cm}$ high and $11 \mathrm{~cm}$ diameters until hatching and observed daily under a stereuoscopic microscope. Crawlers were observed daily, and transferred to fresh potato tubers in other plastic cups using fine hair brush. Dead and stuck nymphs were recorded and removed from the plastic cups. Larval growth and moults were recorded daily. The number of days from hatching to last moult for female nymphs was also recorded.

These groups of nymphs were examined daily until death of the adult females and the following observations were recorded. The development time (days) from the first instar (crawler) of mealybug to the onset of oviposition was recorded for each of the three nymphal instars under three tested degrees of temperature $\left(20,25\right.$, and $\left.30{ }^{\circ} \mathrm{C}\right)$ by checking for exuvia which were visible through the loose waxy filaments. The nymphs for each replicate were observed daily under a dissecting microscope at a magnification of $10 \mathrm{x}$.

Survival rate of each instar was recorded by counting the number of individuals that had successfully molted to the next instar. The overall survival rate from egg to adult female or male at each temperature treatment was determined by the number of adult females (or males) divided by the total number of eggs. The life span of adult females was simply measured from adult eclosion until death .Maturity recorded as the sum of the pre-oviposition, and post-oviposition time.

The colony which maintained as mentioned above was monitored daily to ascertain when female citrus mealybugs began to oviposit. The onset of oviposition was determined by the presence of a clearly visible white tuft of wax beneath the female abdomen. Twenty preovipositing females were randomly assigned at each temperature degree for egg counting. Females collected from the colony and placed into plastic cups containing potato tuber as an oviposition site. After the females start laying eggs, eggs were collected daily and counted to determine the fecundity of each female.

The experiments were completely randomized design. Mean of the response variable was calculated and used in subsequent analyses in all experiments. One-way analysis of variance (ANOVA) was performed according to Steel and Torrei (1980). Means were compared using least significant difference (LSD) test.

\subsection{Life Table Parameters}

The main purpose of life table parameters leads to predict the rate of population growth of Planococcus citri.

A certain number of eggs were taken from the isolated adult female's immediately after deposition and placed on potato tubers confined in plastic cups $4 \mathrm{~cm}$ high and $11 \mathrm{~cm}$ diameters until hatching. 20 virgin females were isolated soon after the third moult and observed daily to record the daily survival 
rate (Lx). The laid eggs were calculated daily and removed from beneath adult females . The duration periods of immature stages of $1^{\text {st }}, 2^{\text {nd }}$ and $3^{\text {rd }}$ instar were calculated. Daily adult numbers observation from the first day of female eclosion until complete females death, daily survival rate ( $\mathrm{Lx}$ ) and female fecundity $(\mathrm{mx})$ were calculated according to equation of life tables to predict the growth rate of the population under laboratory conditions of temperatures under $20 \pm 2^{\circ} \mathrm{C}, 25 \pm 2^{\circ} \mathrm{C}, 27 \pm 2^{\circ} \mathrm{C}$ and $30 \pm 2^{\circ} \mathrm{C}$.

From the fertility and survival schedules, several population growth parameters including the net reproductive rate $\left(R_{\mathrm{o}}\right)$, finite rate of increase $(\lambda)$, mean generation time $(T)$, doubling time $(D T)$, and intrinsic rate of natural increase $(\mathrm{rm})$ were calculated using the formulas suggested by Carey (2001), where $\mathrm{x}$ is the age of individuals in days, $\mathrm{lx}$ is the age-specific survival, and $\mathrm{mx}$ is the age-specific number of female offspring.

\section{RESUlTS AND DISCUSSION}

\subsection{Temperature Effect on the Development of the Citrus Mealybug Females}

The effect of three degrees of temperature $\left(20,25\right.$, and $\left.30^{\circ} \mathrm{C}\right)$ on the female development stages of $P$. citri is presented in Table (1). Citrus mealybug females successfully developed into adults at temperatures ranging from 20 to $30^{\circ} \mathrm{C}$.

The duration of nymphal instars under the temperature of $20^{\circ} \mathrm{C}$ recorded $12.5,11.89$ and 10.0 days for first-, second- and third-instar nymphs of $P$. citri females, respectively. The preoviposition period, oviposition period, and postoviposition period were $12.2,15.2$, and 0.8 days, respectively. Data in Table (1) shows that the average of longevity of females of citrus mealy bug reared under $20^{\circ} \mathrm{C}$ was 28.2 days, while the total development time from egg to end life of females of citrus mealy bug reared under $20^{\circ} \mathrm{C}$ was 63.20 days.

Under the temperature of $25^{\circ} \mathrm{C}$ the duration of immature stages recorded 10.159 .8 and 9.95 days for first-, second- and third-instar nymphs of $P$. citri females, respectively. The preoviposition period, oviposition period, and postoviposition period were 10.10, 9.20, and1.5 days, respectively. Data in Table (1) shows that the average of longevity of adult females of citrus mealy bug reared under $25^{\circ} \mathrm{C}$ was 20.8 days, while the total development time was 51.10 days for females of citrus mealy bug reared under $25^{\circ} \mathrm{C}$.

Under the temperature of $30^{\circ} \mathrm{C}$ the longest stadium for female nymphs was the third nymphal instar (8.3 days) while that of first and second instars were 6.1 and 7.1days, respectively. The preoviposition period, oviposition period, and postoviposition period were $8.15,9.65$, and 2.25 days, respectively. Data in Table (1) shows that the average of females longevity of citrus mealy bug reared under $30^{\circ} \mathrm{C}$ was 20.05 days and the total development time was 41.55 days.

Table1. Duration of nymphal and adult stages of females of planococcus citri reared on potato tubers under different temperature

\begin{tabular}{|c|c|c|c|c|c|c|c|c|}
\hline \multirow[b]{3}{*}{$\begin{array}{c}\text { Temperature } \\
\left({ }^{\circ} \mathrm{C}\right)\end{array}$} & \multicolumn{7}{|c|}{ Duration (day, mean \pm S.D.) } & \multirow[b]{3}{*}{$\begin{array}{l}\text { Total life } \\
\text { cycle }\end{array}$} \\
\hline & \multicolumn{3}{|c|}{ Nymphal periods } & \multicolumn{4}{|c|}{ Adult female } & \\
\hline & $1^{\text {st }}$ & $\begin{array}{c}2^{\text {nd }} \\
\text { instar }\end{array}$ & $\begin{array}{c}3^{\text {rd }} \\
\text { instar }\end{array}$ & $\begin{array}{c}\text { Pre } \\
\text { oviposition } \\
\text { period }\end{array}$ & $\begin{array}{l}\text { Oviposition } \\
\text { period }\end{array}$ & $\begin{array}{c}\text { Post } \\
\text { oviposition } \\
\text { period }\end{array}$ & $\begin{array}{l}\text { Longevity } \\
\text { (adult) }\end{array}$ & \\
\hline 20 & $\begin{array}{c}12.5^{\mathrm{a}} \\
\pm \\
1.64\end{array}$ & $\begin{array}{c}11.89^{\mathrm{a}} \\
\pm \\
2.32\end{array}$ & $\begin{array}{l}10.00^{\mathrm{a}} \\
\pm \\
1.50\end{array}$ & $\begin{array}{c}12.20 \\
\pm \\
0.92\end{array}$ & $\begin{array}{c}15.20 \\
\pm \\
2.53\end{array}$ & $\begin{array}{c}0.80 \\
\pm \\
0.92\end{array}$ & 28.2 & $\begin{array}{c}63.20 \\
\pm \\
4.54\end{array}$ \\
\hline 25 & $\begin{array}{c}9.85^{\mathbf{b}} \\
\pm \\
0.81\end{array}$ & $\begin{array}{c}10.15^{\mathbf{b}} \\
\pm \\
2.89\end{array}$ & $\begin{array}{l}9.95^{\mathrm{a}} \\
\pm \\
2.52\end{array}$ & $\begin{array}{c}10.10 \\
\pm \\
1.91\end{array}$ & $\begin{array}{l}9.20 \\
\pm \\
2.53\end{array}$ & $\begin{array}{c}1.50 \\
\pm \\
1.35\end{array}$ & 20.8 & $\begin{array}{c}51.10 \\
\pm \\
3.21\end{array}$ \\
\hline 30 & $\begin{array}{c}6.10^{\mathrm{c}} \\
\pm \\
1.37 \\
\end{array}$ & $\begin{array}{c}7.10^{\mathbf{c}} \\
\pm \\
1.94 \\
\end{array}$ & $\begin{array}{c}8.30^{b} \\
\pm \\
1.72 \\
\end{array}$ & $\begin{array}{c}8.15 \\
\pm \\
1.73 \\
\end{array}$ & $\begin{array}{c}9.65 \\
\pm \\
3.05\end{array}$ & $\begin{array}{c}2.25 \\
\pm \\
1.16\end{array}$ & 20.05 & $\begin{array}{c}41.55 \\
\pm \\
4.07 \\
\end{array}$ \\
\hline L. S.D 0.05 & 0.836 & 1.505 & 1.230 & - & - & - & - & - \\
\hline
\end{tabular}

Mean values followed by different letters in the same columns are significantly different $(P<0.05$, SNK, after one-way ANOVA).

Table (1) shows the female longevity of $P$. citri when reared under 20,25 , and $30{ }^{\circ} \mathrm{C}$. Female longevity was the longest at $20^{\circ} \mathrm{C}$ where the female $P$. citri survived for 28.2 day after adult eclosion. The female longevities are 20.8 days and 20.05 days at 20 and $25^{\circ} \mathrm{C}$ respectively. Our findings agree 
with the results of Chong et al. (2008) that female longevity of $M$. hirsutus was the longest at $20^{\circ} \mathrm{C}$ since the female survived for $28.2 \mathrm{~d}$ after adult eclosion. The longevities of females were similar at 25 ${ }^{\circ} \mathrm{C}$ (21.2 day), $27{ }^{\circ} \mathrm{C}$ (19.9 day), and $30^{\circ} \mathrm{C}$ (19.5 day). However, no significant difference in adult longevity of males and females of the mealybug, Paracoccus marginatus reared on different hosts. Mean longevity of adult males and females kept at $25{ }^{\circ} \mathrm{C}$ was 2.3 day and 21.2 day, respectively (Amarasekare et al., 2008). Adult longevity of the citrus mealybug, P. citri at three different constant temperatures $\left(18,24\right.$ and $30^{\circ} \mathrm{C}$ ) on citrus was 17.3, 13.1 and 11.7 days, respectively (Ahmed and AbdRabou, 2010).

Our results are in full agreement with results of Ahmed and Abd-Rabou (2010) who found that mean durations of the first instar of $P$. citri were $8.5,6.0$ and 3.4 days at 18,24 and $30^{\circ} \mathrm{C}$, respectively. Second instar lasted for 11.5, 9.2 and 5.2 days, respectively. While third nymphal stadium were 12.7, 10.0 and 8.2 , respectively.

Results of Goldasteh et al. (2009) indicated that at $35^{\circ} \mathrm{C}$, the survival rate of the second-instar nymphs of $P$. citri was $5 \%$, but all of them died during the third instar. At $15^{\circ} \mathrm{C}$, none of the females were successful in oviposition. The optimal temperature for survival of nymphs in all instars seems to be $25^{\circ} \mathrm{C}$. However, developmental rates increased as the temperature increased between 20 and $27^{\circ} \mathrm{C}$ for both male and female mealybugs. Chong et al. (2008) found that the nymphal development of females decreased at $30^{\circ} \mathrm{C}$, where the developmental time of second- and third-instar females were between those at 20 and $25^{\circ} \mathrm{C}$. Chong et al., (2003) found that the total duration of development of female of madeira mealybug, Phenacoccus madeirensis was $\approx 30 \mathrm{~d}$ at $25^{\circ} \mathrm{C}, 46 \mathrm{~d}$ at $20^{\circ} \mathrm{C}$, and $66 \mathrm{~d}$ at $15^{\circ} \mathrm{C}$. Adult longevity at $25^{\circ} \mathrm{C}$ was $\approx 3$ and $20 \mathrm{~d}$ for males and ovipositing females, respectively.

Table (1) showed that the pre-oviposition periods for females of citrus mealy bug recorded 12.20, 15.20 , and 0.80 days at 20,25 , and $30^{\circ} \mathrm{C}$, respectively. The oviposition periods for females of citrus mealy bug recorded $10.12,9.20$, and 1.5 days at 20,25 , and $30^{\circ} \mathrm{C}$, respectively. The postoviposition periods for females of citrus mealy bug recorded $8.15,9.65$, and 2.25 days at 20,25 , and $30^{\circ} \mathrm{C}$, respectively. However, The prereproductive periods of $M$. hirsatus were the longest at 20 (12.6 day) and $30^{\circ} \mathrm{C}$ (12.6 day) and the shortest at 27 (10.8 day) and $25^{\circ} \mathrm{C}(9.3$ day). The reproductive period of M. hirsutus was the longest at $20^{\circ} \mathrm{C}\left(11\right.$ day), whereas those at $25-30^{\circ} \mathrm{C}$ reproduced for $7-8$ day (Chong et al., 2008).

Table (1) showed that female longevity of $P$. citri were 28.2, 20.8 and 20.05 days when reared under 20,25 , and $30{ }^{\circ} \mathrm{C}$, respectively. Data in Table (1) indicated also that the total development times of females were recorded $63.2,51.10$, and 41.55 days at 20,25 , and $30^{\circ} \mathrm{C}$, respectively. However, citrus mealybug females successfully developed into adults at temperatures ranging from 15 to $32^{\circ} \mathrm{C}$. The development time from egg to adult female of $P$. citri decreased gradually for laboratory rearing from $25^{\circ} \mathrm{C}$ to $15^{\circ} \mathrm{C}$ ). It increased at temperatures higher than $25^{\circ} \mathrm{C}$ (Goldasteh et al., 2009). These data are in agreement with the results of Walton and Pringle (2005) who studied Pseudococcus ficus (Signoret) on Waltham Cross grapevines. Cloyd (1999) reported 33.7 days for development of P. citri on red variegated coleus. The generation time of the citrus mealybug, P. citri at three different constant temperatures $\left(18,24\right.$ and $30^{\circ} \mathrm{C}$ ) was $47.3,34.2$ and 21.4 days, respectively (Ahmed and AbdRabou, 2010). Our obtained results agree with the results of Ahmed and Abd-Rabou (2010) who indicated that $30^{\circ} \mathrm{C}$ was the best degree of temperature for the citrus mealybug, $P$. citri life because it resulted in the highest oviposition (362.3 eggs/female), and adult longevity (11.7 days). Results of Goldasteh et al. (2009) indicate that $25^{\circ} \mathrm{C}$ is the optimal temperature for $P$. citri development among the tested temperatures.

\subsection{Temperature Effect on the Development of the Citrus Mealybug Males}

Males of mealybug develop through four immature instars, $1^{\text {st }}$ and $2^{\text {nd }}$ nymphs, prepupa and pupa. The effect of three degrees of temperature $\left(20,25\right.$, and $\left.30^{\circ} \mathrm{C}\right)$ on the male development of $P$. citri is presented in Table (2). Citrus mealybug males successfully developed into adults at temperatures ranging from 20 to $30^{\circ} \mathrm{C}$.

Table (2) shows means periods of $1^{\text {st }}$ nymphal instar, $2^{\text {nd }}$ nymphal instar, $3^{\text {rd }}$ nymphal instars, prepupa and $4^{\text {th }}$ pupal instar of male of $P$. citri reared on potato tubers under the temperature of $20^{\circ} \mathrm{C}$. It was observed that development time of the four instars of male adult differed significantly at the three tested temperatures. The $1^{\text {st }}$ nymphal instar for males of citrus mealybug recorded $13.1,7.23$, and 5.7 days at 20,25 , and $30^{\circ} \mathrm{C}$, respectively. The $2^{\text {nd }}$ nymphal instar recorded $11.3,8.0$, and 6.5 days at 20 , 
25 , and $30^{\circ} \mathrm{C}$, respectively. The $3^{\text {rd }}$ nymphal instar recorded $11.0,9.17$, and 7.65 days at 20,25 , and $30^{\circ} \mathrm{C}$, respectively. The pupal instar of males of citrus mealybug recorded 7.8, 7.0, and 4.1 days at 20, 25 , and $30^{\circ} \mathrm{C}$, respectively.

Generally, the male nymphal periods of citrus mealybug reared under laboratory condition $\left(\right.$ at $20^{\circ} \mathrm{C}$ to $30^{\circ} \mathrm{C}$ ) were reduced gradually by increasing the rearing degree of temperature for the four tested nymphal instars. However, Goldasteh et al. (2009) mentioned that females and males of Planococcus citri had the highest average longevity at 18 and $20^{\circ} \mathrm{C}$, respectively. The lowest longevity of both females and males occurred at $25^{\circ} \mathrm{C}$. Mean adult longevity of females decreased with increasing temperatures, but this was reversed with a slight difference at 28 and $32^{\circ} \mathrm{C}$. Walton and Pringle (2005) stated that more males at extreme temperature (32C) can be seen as an adoptive response and a result of stress, producing greater genetic variability and increasing the probability of survival of the population (Margolies and Wrensch, 1996; and Walton and Pringle, 2005).

Table2. Development time of adult males of Planococcus citri reared on potato tubers under different temperatures

\begin{tabular}{|c|c|c|c|c|}
\hline \multirow{2}{*}{$\begin{array}{c}\text { Temperature } \\
\left({ }^{\circ} \mathrm{C}\right)\end{array}$} & \multicolumn{4}{|c|}{ Nymphal period (day, mean \pm S.D.) } \\
\cline { 2 - 5 } & $\begin{array}{c}\mathbf{1}^{\text {st }} \text { nymphal } \\
\text { instar }\end{array}$ & $\begin{array}{c}\mathbf{2}^{\text {nd }} \text { nymphal } \\
\text { instar }\end{array}$ & $\begin{array}{c}\mathbf{3}^{\text {rd }} \text { nymphal } \\
\text { instar }\end{array}$ & $\begin{array}{c}\mathbf{4}^{\text {th }} \text { pupa } \\
\text { Instar }\end{array}$ \\
\hline 20 & $13.10^{\mathrm{a}} \pm 3.56$ & $11.30^{\mathrm{a}} \pm 3.07$ & $11.00^{\mathrm{a}} \pm 2.58$ & $7.80^{\mathrm{a}} \pm 1.29$ \\
\hline 25 & $7.23^{\mathrm{b}} \pm 2.32$ & $8.00^{\mathrm{b}} \pm 2.45$ & $9.17^{\mathrm{b}} \pm 2.80$ & $7.00^{\mathrm{a}} \pm 1.83$ \\
\hline 30 & $5.70^{\mathrm{c}} \pm 1.60$ & $6.50^{\mathrm{c}} \pm 1.84$ & $7.65^{\mathrm{b}} \pm 3.00$ & $4.10^{\mathrm{b}} \pm 1.12$ \\
\hline L. S.D $\mathbf{0 . 0 5}_{\mathbf{n y y y}}$ & 1.58 & 1.62 & 1.73 & 1.94 \\
\hline
\end{tabular}

Mean values followed by different letters in the same columns are significantly different $(P<0.05$, SNK, after one-way ANOVA).

Generally, rearing the present insect under laboratory conditions at controlled temperature indicated the rate of population growth and effect of the cold or the worm weather on the presence of different stages of mealybug. Consequently, the best time of pest control is predictable. However, although these results are valuable as a first step for establishment an IPM program to control citrus mealybug in Egypt, more research needs to be conducted to determine the effect of fluctuating temperatures, various host plant cultivars, and other environmental factors on $P$. citri performance.

However, temperature has profound effects on insect life history parameters such as development, survival, and reproduction. The response of insects to temperature can be important in predicting the potential geographical range of a species and in developing phenological models to predict population dynamics and the timing of various stages for planning control or survey programs (Keena, 2006). Based on demographic studies, we can estimate extinction probabilities, predict life history evolution, anticipate outbreaks of pest species, analyze population stability, and examine the dynamics of colonizing or invading species (Vargas et al., 1997).

\subsection{Fecundety}

Table (3) shows the number of deposited eggs per female of citrus mealybug, Planococus citri, at controlled degrees of temperature. The highest average of egg laying per female of $P$. citri was recorded at $30^{\circ} \mathrm{C}$ with a number of $340.1 \mathrm{eggs}$, while the average numbers of egg laying were 62.1 and 276.8 eggs per female at 20 and $25^{\circ} \mathrm{C}$, respectively. No significant difference was observed between the number of eggs laid by females of $P$. citri reared either at 25 or $30^{\circ} \mathrm{C}$, while other females reared at $20^{\circ} \mathrm{C}$ and fed on the same food (potato tubers) gave fewer number of eggs for each female and siginificant difference were found among these females and other reared under controlled condition of 25 and $30^{\circ} \mathrm{C}$. However, Goldasteh et al. (2009) noted that the highest number of eggs laid per female of $P$. citri was recorded at $23^{\circ} \mathrm{C}$. Chong et al. (2003) found that temperature had a strong influence on fecundity of the madeira Mealybug, Phenacoccus madeirensis. Fecundity was highest at $20^{\circ} \mathrm{C}$, with an average of 491 eggs, which was equal to 27 eggs per day for 13 day. Females at $25^{\circ} \mathrm{C}$ had the lowest fecundity. A female at $25^{\circ} \mathrm{C}$ produced 288 eggs in 8 day, which averaged 36 eggs per day.

Fecundity of $P$. citri females reared at controlled temperature females fed on potato tubers compared with previous studies i.e Sadof et al. (2003) indicated that fecundity of mealybugs reared on butternut squash in a growth chamber at $24 \pm 2^{\circ} \mathrm{C}, 60-70 \% \mathrm{RH}$, on green plants (175.65 eggs) was significantly lower than those on red-variegated plants (191.97 eggs) and numerically lower than those on yellowvariegated plants (181.29 eggs). Also, female mealybug, Maconellicoccus hirsutus, incubated at $30^{\circ} \mathrm{C}$ 


\section{A. El-Aw et al.}

produced a significantly lower number of eggs (103 eggs per female). The fecundity of M. hirsutus was similar at 20 (260 eggs), 25 (300 eggs), and $27^{\circ} \mathrm{C}$ (274 eggs) (Chong et al., 2008).

Table (3) and Fig (1) show the daily egg laying per female, when females were reared on potato tubers at $20^{\circ} \mathrm{C}$. The daily egg laying was fewer than others reared at $25^{\circ} \mathrm{C}$. The maximum rate of daily egg laying was recorded at the ninth day old with an average of 7.30 egg per female. While some of these females prohibited to laying eggs at tenth day age, while other females were laid eggs until eighteenth day. Generally the highest rate of egg laying was recorded through 1 to 12 days of adult age.

Data presented in and Fig (1) show that the daily egg laying from the $1^{\text {st }}$ day of adult emergence with an average per female (22.2 eggs) and increased gradually to the topmost at the fifth day of the beginning egg laying (43.7eggs). The rate of egg laying decreased gradually from the sixth day old. Some of these females completely prohibited egg laying from the seventh day age and others continued to laying eggs until fourteen days old. Generally the highest rate of egg laying was recorded through the $1^{\text {st }}$ week of adult age.

Table3. Effect of three degrees of temperature on the rate of egg laying of Planococcus citri

\begin{tabular}{|c|c|c|c|}
\hline \multirow{2}{*}{ Females } & \multicolumn{3}{|c|}{ Number of eggs laid per female } \\
\cline { 2 - 4 } & $\mathbf{2 0}^{\circ} \mathbf{C}$ & $\mathbf{2 5}^{\circ} \mathrm{C}$ & $\mathbf{3 0}^{\circ} \mathrm{C}$ \\
\hline 1 & 94 & 286 & 225 \\
\hline 2 & 153 & 231 & 361 \\
\hline 3 & 67 & 164 & 295 \\
\hline 4 & 20 & 376 & 301 \\
\hline 5 & 105 & 318 & 282 \\
\hline 6 & 47 & 375 & 401 \\
\hline 7 & 40 & 429 & 580 \\
\hline 8 & 13 & 270 & 392 \\
\hline 9 & 55 & 101 & 254 \\
\hline 10 & 27 & 218 & 310 \\
\hline Average \pm S.D. & $\mathbf{6 2 . 1}^{\mathbf{b}} \pm \mathbf{4 3 . 8 8}$ & $\mathbf{2 7 6 . 8}^{\mathbf{a}} \pm \mathbf{1 0 2 . 1}$ & $\mathbf{3 4 0 . 1}^{\mathbf{a}} \pm \mathbf{1 0 1 . 3 6 0}$ \\
\hline L.S.D. $\mathbf{0 . 0 5}$ & & $\mathbf{7 9 . 7 3}$ \\
\hline
\end{tabular}

Mean values followed by different letters in the columns are significantly different $(P<0.05$, SNK, after oneway ANOVA).

Data in Fig (1) show that the maximum average daily eggs per female for citrus mealybug females reared on potato tubers at $30^{\circ} \mathrm{C}$ was achieved at fourth day old (54.10 eggs per female).At the fifth day old the deposited eggs decreased gradually to stop at the fifteenth day old of citrus mealybug females.

Generally the data show that the rate of daily eggs per female is affected by the degree of temperature, where the maximum rate of daily eggs per female was recorded for citrus mealybug females when females were reared on potato tubers at $30^{\circ} \mathrm{C}$, followed by 25 and $20^{\circ} \mathrm{C}$, with values $54.10,43.7$ and 7.03 eggs per female, respectively.

On the other hand, the deposited rate of daily eggs per female is increase with age progressive, then decrease gradually until the deposited eggs stopping (Fig 1).

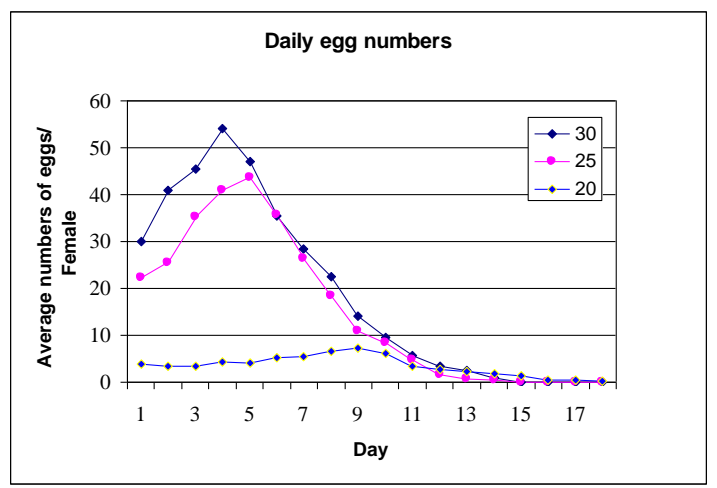

Fig1. Average daily egg deposited per female of Planococcus citri fed on potato tubers under 20,25 , and $30{ }^{\circ} \mathrm{C}$ Our data indicated that the highest total fecundity ( 340 egg per female) occurred at $30^{\circ} \mathrm{C}$. Printz (1923) and Bodenheimer and Guttfeld (1929) found that P. citri produces 12 and 180 eggs per female 
at 17 and $21^{\circ} \mathrm{C}$, respectively. According to the study of Copland et al. (1985), P. citri lays fewer than 100 eggs above $30^{\circ} \mathrm{C}$, but can lay over 400 at $18^{\circ} \mathrm{C}$.

It is concluded that mean number of eggs for adult females of $P$. citri increased with increasing temperatures. However, Mafi and Radjabi (1997) reported that the mean numbers of eggs per female of $P$. citri were 150,180 , and 195 on citrus leaves at 19,23 , and $27^{\circ} \mathrm{C}$ with 70,75 , and $80 \% \mathrm{RH}$, respectively, which are also lower than those obtained in our results at near temperatures. These differences may be due to different host plants and experimental conditions.

\subsection{Life Table Parameters}

Age-specific survival and fertility tables were constructed using age $(x)$, age specific survival rates $(l x)$, age specific fecundity $(m x)$ (Andrewartha and Brich, 1954). Several population growth parameters including intrinsic rate of increase $(\mathrm{rm})$, net reproductive rate $\left(R_{0}\right)$, finite rate of increase $(\lambda)$, mean generation time $(T)$, doubling time $(D T)$, and intrinsic rate of increase $(\mathrm{rm})$ were estimated based on the recorded data in fertility and survival schedules (Carey, 2001). The estimation of $r m, R_{0}$, $\lambda, T$ and $D T$ was carried out by using Proc GLM of SAS statistical package (SAS Institute, 2001).

In specific environmental conditions, it is practical to use the intrinsic rate of natural increase $(\mathrm{rm})$; an important demographic parameter, for predicting the potential of population growth of an animal (Ricklefs and Miller, 2000). The $r m$ value for $P$. citri (Table 4) reared on potato tubers as a host plant were $0.064,0.09,0.128$ and 0.129 for insect reared at $20^{\circ} \mathrm{C}, 25^{\circ} \mathrm{C}, 27^{\circ} \mathrm{C}$ and $30^{\circ} \mathrm{C}$, respectively . These values indicated that reproductive potential for $P$. citri were affected with increasing the rearing degrees of temperature and carefully estimated the prediction of raising or reducing the population growth. However, the $r m$ value of $C$. montrouzieri was higher than that of its prey, P. citri, on coleus at $28^{\circ} \mathrm{C}(0.14 \pm 0.005)$ (Goldasteh et al., 2009).

Data presented in Table (4) clearly indicated the relationship between the temperature degrees and the main biological data. These data will be summarized in life table parameters to show the rate of population growth under designated laboratory conditions. Data in Table (4) show that the total number of daughters per female at $20 \pm 2{ }^{\circ} \mathrm{C}$ was 62.61 compared with $136.88,380$ and 339.62 daughters per female at 25,27 and $30{ }^{\circ} \mathrm{C}$, respectively. These values mean that the females fecundity increased gradually by increasing the degrees of temperature through a range of $20-30{ }^{\circ} \mathrm{C}$. So, average number of daughters per females at 27 and $30^{\circ} \mathrm{C}$ were very related; 380 and 339.62 at 27 and $30{ }^{\circ} \mathrm{C}$, respectively.

The $2^{\text {nd }}$ parameters was the generation time (Gt) of $P$. citri reared at $20,25,27$ and $30{ }^{\circ} \mathrm{C}$ show that reduction of generation period by increasing the rate of degree of temperature. These values ranked to $64.45,50,46.35$ and 44.88 for insect reared at $20,25,27$ and $30^{\circ} \mathrm{C}$, respectively. So, the value followed the same trend of increase. While intrinsic rate of natural increase (rm) were 0.064, 0.09, 0.128 and 0.129 for insect reared at $20,25,27$ and $30^{\circ} \mathrm{C}$, respectively.

The value of Dt (total days for population to double) decreased gradually with increase degree of temperature. These values were $10.83,7.7,5.41$ and 5.37 at $20,25,27$ and $30^{\circ} \mathrm{C}$, respectively.

Other parameters as $\mathrm{mx}$ (daily egg deposited per female) were estimated from 1st day of oviposition period until completely prohibited egg laying at 20, 25, 27 and $30^{\circ} \mathrm{C}$ were $134.59,338.32,417.17$, and 395.36, respectively. While the survival rate of insect were recorded and lx.mx were estimated.

Table4. Life table parameters of P. citri reared in the laboratory under four different degrees of temperatures

\begin{tabular}{|c|c|c|c|c|}
\hline \multirow{2}{*}{ Parameters } & \multicolumn{4}{|c|}{ Temperature $\left({ }^{\circ} \mathrm{C}\right)$} \\
\cline { 2 - 5 } & $\mathbf{2 0}$ & $\mathbf{2 5}$ & $\mathbf{2 7}$ & $\mathbf{3 0}$ \\
\hline R0 & 62.61 & 136.88 & 380 & 339.62 \\
\hline Ratio & 1.00 & 2.186 & 6.069 & 5.424 \\
\hline Gt & 64.45 & 50.00 & 46.35 & 44.88 \\
\hline Ratio & 1.00 & 0.776 & 0.719 & 0.696 \\
\hline Rm & 0.064 & 00.09 & 0.128 & 0.129 \\
\hline Ratio & 1.00 & 1.406 & 2.00 & 2.016 \\
\hline$\lambda$ & 1.066 & 1.09 & 1.14 & 1.137 \\
\hline Ratio & 1.00 & 1.023 & 1.064 & 1.285 \\
\hline Dt & 10.83 & 7.7 & 5.41 & 5.37 \\
\hline Ratio & 1.00 & 0.711 & 0.500 & 0.496 \\
\hline mx & 134.59 & 338.32 & 417.17 & 395.36 \\
\hline
\end{tabular}


It is observed from data in Table (4) that Rm values were $0.064,0.09$, and 0.129 for 20,25 , and $30^{\circ} \mathrm{C}$, respectively. The $\mathrm{Rm}$ value at $25^{\circ} \mathrm{C}$ was increased by about 1.4 -fold than those of $20{ }^{\circ} \mathrm{C}$. Also, the $\mathrm{Rm}$ value at $30^{\circ} \mathrm{C}$ was increased by about 1.4 -fold than those of $25^{\circ} \mathrm{C}$. According to this finding we suggest the following equation to calculate the expected $\mathrm{Rm}$ value using a known $\mathrm{Rm}$ at a certain degree of temperature $\left({ }^{\circ} \mathrm{C}\right)$ :

$\mathbf{R m}_{\left({ }^{\circ} \mathbf{C}+5\right)}=\mathbf{R m}_{\left({ }^{\circ} \mathbf{C}\right)} \times \mathbf{k}$ (whereas $\mathrm{k}$ is a constant value $=1.4$ )

Generally, the life table parameters were varied according to the degrees of temperatures as indicated in Table (4). These values help us to predict the population density of insects under field condition and help to determine the date and methods of insect control.

These studies are very important to estimate the total number of insects gained by laboratory studies under control rearing conditions .The mass production is very important for test the efficiency of some insecticides and other biological studies. Other studies about the irradiation and insect sterilization of insects depend on the life table parameters under controlled temperature.

Knowledge of the life cycle of citrus mealy bugs is important to the success of its management program. Several studies were conducted by many researches i.e. Persad and Khan (2002) who reported that the $\mathrm{R}_{0}$, T, DT and $\lambda$ were 227.18 females per female, 40.13 and 5.13 days and 1.14 day1 , respectively, when reared on M. hirsutus. Özgokce et al. (2006) observed that $\mathrm{R}_{\mathrm{o}}, \mathrm{T}$, DT and $\lambda$ was 340.703 females per female, 59.350 and 7.2 days and 1.101 day-1, respectively, when reared on $P$. citri. Goldasteh et al., (2009) found that the $\mathrm{R}_{0}, \mathrm{rm}, \lambda$, DT and mean generation time (GT) values for $P$. citri were significantly different at various constant temperatures. The $\mathrm{R}_{\mathrm{o}}$ was the highest at $25^{\circ} \mathrm{C}$, with 154 eggs per female per generation, and the lowest at $32^{\circ} \mathrm{C}$, with 8.83 eggs per female per generation. The rm of $P$. citri rose with temperature to reach a maximum at $25^{\circ} \mathrm{C}$ and then declined at 28 to $32^{\circ} \mathrm{C}$. The highest values of $\mathrm{rm}$ and $\lambda$ and the lowest values of DT and $\mathrm{T}$ occurred at $25^{\circ} \mathrm{C}$, suggesting that this is the optimal temperature for $P$. citri.

The intrinsic rate of natural increase $(\mathrm{rm})$ of $P$. citri estimated in the study of Goldasteh et al. (2009) ranged from 0.055 to 0.170 female per female per day for rearing on $\left(25^{\circ} \mathrm{C}-15^{\circ} \mathrm{C}\right)$. These values are similar to the values reported by Walton and Pringle (2005) for P. ficus at 20 (0.068), 25 (0.169), and $27^{\circ} \mathrm{C}(0.131)$, but they were higher at $30^{\circ} \mathrm{C}$ and very close at $18^{\circ} \mathrm{C}$. The highest intrinsic rate of natural increase $(\mathrm{rm})$ of $P$. citri occurred at $25^{\circ} \mathrm{C}$ and revealed high reproduction ability of citrus mealybug females at this temperature. Also, the mean generation time $(\mathrm{Gt})$ was shortest at $25^{\circ} \mathrm{C}$. This result indicates that development of $P$. citri took place faster at this temperature than at the other temperatures.

According to Yang and Sadof (1995), the intrinsic rate of natural increase for P. citri reared on red variegated coleus was 0.122 females/female/day. The intrinsic rate of natural increase is a composite statistic that takes into account life history parameters such as development rate, fecundity, longevity (survival), and sex ratio (Carey, 1993). Thus, it is one of the most important criteria used for evaluating the influence of temperature on life history of a pest. The values of population growth parameters of $P$. citri (except generation time) at $28^{\circ} \mathrm{C}$ in this study were higher than data reported for M. hirsutus by Persad and Khan (2002). Polat et al. (2008) investigated development, longevity, fecundity and life-table parameters of Planococcus citri (Hemiptera: Pseudococcidae) feeding on Nerium oleander, Schefflera arbicola, Kalanchoe blossfeldiana and Sygonium podophyllum at $28 \pm 1^{\circ} \mathrm{C}, 65 \pm 10 \% \mathrm{RH}$ and 16L: 8D under laboratory conditions. They found that the highest reproductive rate $\left(\mathrm{R}_{\mathrm{o}}\right)$ occurred on $S$. podophyllum, with 205.46 female offspring per female, and the lowest occurred on S. arbicola, with 32.27 female offspring per female. The intrinsic rate of increase (rm) was significantly different among hosts, with the highest rate $(0.138$ female offspring per female per day) on $S$. podophyllum. However, mealybugs possess a waxy covering that protects them from insecticide sprays, so additional control methods are often times necessary (Copeland et al., 1985 and Walker, 2000). Our findings showed citrus mealybug performances to be highly affected by temperature. 


\section{REFERENCES}

Ahmed, N. H. and S. M. Abd-Rabou. 2010. Host plants, geographical distribution, natural enemies and biological studies of the citrus mealybug, Planococcus citri (Risso) (Hemiptera: Pseudococcidae). Egypt. Acad. Journal of Biological Sci., 3 (1): 39- 47.

Amarasekare, K. G., C. M. Mannion, L. S. Osbrne, and N. D. Epsky. 2008. Life History of Paracoccus marginatus (Hemiptera: Pseudococcidae) on Four Host Plant Species Under Laboratory Conditions. Environ. Entomol. 37(3): 630-635

Bodenheimer, F. S., and M. Guttfeld. 1929. Über die Möglichkeiten einer biologischen Bekampfung von Pseudococcus citri Riss. (Rhy. Cocc.) in Palastina. Z. Ang.Entomol. 25, 67.

Carey, J. R. 1993. Applied Demography for Biologists with Special Emphasis on Insects, 211 pp. Oxford Univ. Press, U. K.

Carey, J. R. 2001. Applied demography for biologists with especial emphasis on insects. Oxford Univ. Press, New York, 205.pp.

Chong, J.-H., R. D. Oetting, and M. W. Van Iersel. 2003. Temperature Effects on the Development, Survival, and Reproduction of the Madeira Mealybug, Phenacoccus madeirensis Green (Hemiptera: Pseudococcidae), on Chrysanthemum. Ann. Entomol. Soc. Am. 96 (4): 539543.

Chong, J.-H.; A. L. Roda, C. M. Mannion. 2008: Life History of the Mealybug, Maconellicoccus hirsutus (Hemiptera: Pseudococcidae), at Constant Temperatures. Environ. Entomol. 37(2): 323332.

Cloyd, R. A. 1999. Effects of plant architecture on the attack rate of Leptomastix dactylopii (Howard) (Hymenoptera: Encyrtidae), a parasitoid of the citrus mealybug, Planococcus citri (Risso) (Homoptera: Pseudococcidae). Ph. D. Thesis, Purdue Univ. 59 pp.

Copeland, M. J. W, C. C. D. Tingle, M. Saynor, and A. Panis. 1985. Biology of glasshouse mealybugs and their predators and parasitoids, In: Biol. Pest Con. (Eds. N. W. Hussey and N. Scopes), 82-86. Blandford Press.

Keena, M. A. 2006. Effects of temperature on Anoplophora glabripenis (Coleoptera: Cerambycidae) adult survival, reproduction, and egg hatch. Environ. Entomol. 35, 912-921.

Goldasteh, S., A, A. Talebi, Y. Fathipour, H. Ostovan, A. Zamani, and R. V. Shoushtari. 2009. Effect of temperature on life history and population growth parameters of Planococcus citri (Homoptera, Pseudococcidae) on coleus [Solenostemon scutellarioides (L.) codd.]. Arch. Biol. Sci., Belgrade, 61 (2): 329-336.

Hogendorp, B. K., R. A. Cloyd, and J. M. Swiader. 2006. Effect of Silicon-Based Fertilizer Applications on the Reproduction and Development of the Citrus Mealybug (Hemiptera: Pseudococcidae) Feeding on Green Coleus. J. Econ. Entomol. 102(6): 2198-2208.

Hardy, N. B., P. J. Gullan, R.C. Henderson, and L.G. Cook. 2008. Relationships among scale insects (Hemiptera: Coccoidea: Eriococcidae) of southern beech, Nothofagus (Nothofagaceae), with the first descriptions of Australian species of the Nothofagus-feeding genus Madarococcus Hoy. Invertebrate Systematics, 22: 365-405.

Kosztarab, M. 1996. Scale insects of northeastern North America: identification, biology, and distribution. Virginia Museum of Natural History, Martinsville, VA.

Laflin, H. M. and M. P. Parrella. 2004. Developmental Biology of Citrus Mealybug Under Conditions Typical of California Rose Production. Ann. Entomol. Soc. Amer. 97(5): 982-988.

Mafi, S. A., and G. R. Radjabi. 1997. The identification of mealybugs (Pseudococcidae) in Mazandaran province. M. Sc. Thesis, Faculty of Agriculture, Tarbiat Modares University, 112 pp.

Martines, M. D. I. A., and M. Suris 1987a. Development of Planococcus citri on coffee. Rev. Protect. Veget. 2 (1): 32-36.

Martinez, M. D. I. A., and M. Suris. 1987b. Developmental variations of Planococcus citri using potato tuber as an alternative substrate. Rev. Protect. Veget. 2 (2), 130-133.

Malleshaiah, B. K. Rajagopal, and K. N. M. Gowda 2000. Biology of citrus mealybug, Planococcus citri (Risso) (Hemiptera: Pseudococcidae). Crop Res. 20 (1): 130-133. 
Margolies, D. C. and D.L. Wrensch 1996. Temperature-induced changes in spider mite fitness: offsetting effects of development time, fecundity, and sex ratio. Entomologia Experimentalis et Applicata, 78 (1): 111-118.

Miller, D. R., G. L. Miller, and G. W. Watson. 2002. Invasive species of mealybugs (Hemiptera: Pseudococcidae) and their threat to U.S. agriculture. Proc. Entomol. Soc. Wash. 104: 825-836.

Persad, A., and A. Khan. 2002. Comparison of life table parameters for Maconellicoccus hirsutus, Anagyrus kamali, Cryptolaemus montrouzieri, and Scymnus coccivora. Biol. Cont. 47: 137-149.

Özgokce, M. S., R. Atlihan and I. Karaca 2006. The life table of Cryptolaemus montrouzieri Mulsant (Coleoptera: Coccinellidae) after different storage periods. J. Food, Agric. \& Environ.. 4(1): 282-287.

Ricklefs, S. R. E., G. L. Miller. 2000. Ecology, 3rd ed. Freeman and Company, New York.

Polat, F., S. Lgentürk, and M. B. Kaydan. 2008. Developmental biology of citrus mealybug, Planococcus citri (Risso) (Hemiptera: Pseudococcidae), on ornamental plants. 177-184 In: Branco, M., Franco, J.C. \& Hodgson, C.J. (Editors), International Symposium on Scale Insect Studies, Oeiras, Portugal, 24-27 September 2007. ISA Press, Lisbon, Portuga. 322 pp.

Printz, Y. I. 1923. Reports on the activities of the entomological department of viticulturists for the year 1922-1923. Rev. Appl. Entomol. A, 13.

Ricklefs, S. R. E., Miller, G. L., (2000) Ecology, 3rd ed. Freeman and Company, New York.

Sadof, C. S., J. J. Neal, and R. A. Cloyd. 2003. Effect of variegation on stem exudates of coleus and life history characteristics of citrus mealybug (Pseudococcidae). Environ. Entomol. 32 (3): 463 469.

Serrano, M. S., S. L. Lapointe, and D. E. Meyerdirk. 2001. Attraction of males by virgin females of the malybug Maconellicoccus hirsutus (Hemiptera: Pseudococcidae). Environ. Entomol. 30: 339-345.

SAS Institute (2001). PROC User's Manual. Sixth Edition Version. SAS Institute, Cary, NC.

Steel, R.G.D., and J. H. Torrie. 1980. Principles and procedures of statistics. McGraw-Hill, New York.

Tanwar R.K., P. Jeyakumar, and D. Monga. 2007. Mealybugs and their management,12 p. Technical Bulletin 19, National Centre for Integrated Pest Management, New Delhi, India. Available online: http://www.ncipm.org.in/MealybugPDFs/Bulletin-Mealybugs\%20.

Vargas, R. I., W. A. Walsh, D. T. Kanehisa, E. B. Jang, and J. W. Armstrong. 1997. Demography of four Hawaiian fruit flies (Diptera: Tephritidae) reared at five constant temperatures. Ann. Entomol. Soc. Am. 90: 162-168.

Walker, D.E. 2000. Culturing mealybug parasites. Assoc. Edu. Res. Greenhouse Curators News.13: 1-3.

Walton, V. M., and K. L. Pringle. 2005. Developmental biology of vine mealybug, Planococcus ficus (Signoret) (Homoptera: Pseudococcidae), and its parasitoid Coccidoxenoides perminutus (Timberlake) (Hymenoptera: Encyrtidae). African Entomol. 13 (1): 143-147.

Wittmeyer, J. L., and T. A. Coudron. 2001. Life table parameters, reproductive rate, intrinsic rate of increase, and estimated cost of rearing Podisus maculiventris (Heteroptera: Pentatomidae) on an artificial diet. J. Econ. Entomol. 94(6): 1344-1352.

Yang, J., and C. S. Sadof. 1995. Variegation in Coleus blumei and the life history of citrus mealybug (Homoptera: Pseudococcidae). Environ. Entomol. 24, 1650-1655. 